\title{
A body measurements and sensory evaluation-based classification of lower body shapes for developing customized pants design
}

\author{
MIN DONG \\ DOI: $10.35530 / I T .069 .02 .1381$ \\ YAN HONG \\ KAIXUAN LIU \\ JUNJIE ZHANG \\ MELISSA WAGNER \\ HUIYU JIANG
}

\author{
REZUMAT - ABSTRACT
}

\section{Clasificarea măsurătorilor corpului şi evaluarea senzorială a formelor părții inferioare a corpului} pentru dezvoltarea modelelor personalizate de pantaloni

În lucrarea de față, se aplică o metodă aproximativă de clasificare bazată pe un set fuzzy pentru a identifica formele părții inferioare a corpului pentru o populație țintă, cu scopul de a dezvolta modelul personalizat al pantalonilor. A fost selectat un grup de designeri pentru a identifica dimensiunile cheie şi indicatorii formelor părții inferioare a corpului în ceea ce priveşte modelele de pantaloni de damă. A fost propus un algoritm de clasificare, care utilizează funcții triunghiulare şi trapezoidale fuzzy pentru transformarea indicilor datelor relevante în cinci seturi fuzzy, considerate descriptori lingvistici. S-au definit gradul de importanță şi gradul de similaritate pentru a rezolva conflictele diferiților indicatori. Au fost selectate aleatoriu 125 corpuri umane din populația țintă, au fost măsurate valorile dimensiunilor cheie prin intermediul unui sistem $3 D$ de scanare corporală şi au fost calculați indicatorii importanți ai formelor corpului. Ulterior, au fost create o serie de tabele de decizie şi au fost împărțite formele diferitelor poziții ale părții inferioare a corpului în cinci clase, utilizând metoda setului aproximativ. Rezultatele clasificării au fost validate utilizând o procedură de evaluare senzorială. Rezultatele obținute au contribuit în mod eficient la crearea unor dimensiuni de îmbrăcăminte noi adaptate la o populație țintă şi la realizarea conceptului de personalizare în masă, prin dezvoltarea unor stiluri de îmbrăcăminte personalizate.

Cuvinte-cheie: model de pantaloni, clasificarea formelor părții inferioare a corpului, tehnici fuzzy, seturi aproximative, grad de importanță, grad de similaritate, evaluare senzorială

\section{A body measurements and sensory evaluation-based classification of lower body shapes for developing customized pants design}

In this paper, a fuzzy rough set-based classification method is applied to identify lower body shapes of a target population for developing customized pants design. First, a group of designers is selected for identifying the key dimensions and lower body shape indices related to women pants design. On the basis of this, we propose a classification algorithm, which uses triangle and trapezoid fuzzy membership functions for transforming the indices of the relevant data into five fuzzy sets, regarded as linguistic descriptors. An importance degree and a similarity degree are defined to solve conflicts of different indices. Next, we randomly select 125 human bodies in the target population and measure the key dimension values by means of a 3D body scanning system and then compute important body shape indices. Then, we set up a number of decision tables and respectively divide the shapes of various lower body positions into five classes by using the rough set method. The classification results have been validated by using a sensory evaluation procedure. The obtained results will effectively help to set up new garment sizes adapted to a target population and realize the concept of mass customization by developing personalized or customized garment styles.

Keywords: pants design; lower body shape classification; fuzzy techniques; rough sets; importance degree; similarity degree; sensory evaluation

\section{INTRODUCTION}

Body shape analysis has become especially significant for satisfying the personalized requirements of a target population in garment design and mass customization. By classifying the population, ready-towear products such as pants, can be designed and produced more accurately and individually.

At present, information about body sizes and shapes is obtained from body measurements. During an anthropometric survey, many different body dimensions can be measured on each individual, resulting in thousands of data points, which should be further analysed to identify the significant dimensions that can be used to divide the target population into clusters each having similar body dimensions. These significant body dimensions are known as key dimensions [1]. The first scientific study of body measurements by using key dimensions for garment design was presented in 1941 by O'Brien and Shelton [1]. They used a bivariate distribution technique to develop sizes according to bust and hip girth. Later, Otieno classified children's body shapes according to height and bust girth for upper body garments or hip girth for lower body garments [2]. Hsu applied a bust-to-waist ratio approach to develop body measurement charts for female clothing [3].

In practice, different body positions have different morphological features. Therefore, the existing 
classification criteria are often rough and the fitting level to a specific body shape is not high enough. In addition, the existing body classifications are mainly realized by using classical statistical methods [4-9]. However, in garment design, designers usually describe body shapes using linguistic terms such as fat or thin, tall or short, etc. The classical methods often lead to unsatisfactory results since they cannot be used to process human perception effectively.

Since these linguistic terms reflect designer's conventional expressionsdescribing their imprecise and vague perceptions, fuzzy techniques are very suitable for dealing with this situation [10-12]. On the basis of this, we tried to classify body shapes by using fuzzy clustering method and obtained dynamitic cluster results, butthese results are sometimes quite different from the real situation in garment design [13]. In practice, experienced designer's knowledge and perception, usually leading to very relevant body shape classification results in terms of garment styles and other design elements, have never been exploited in the existing clustering algorithms.

Rough set theory [14], proposed by Pawlak, has become a well-established mechanism for uncertainty management in a wide variety of applications. Particularly, rough set have astrong ability of knowledge classification. Thus, we propose a fuzzy rough set-based method for pants design in order to accurately classify the shapes of various body positions of a given population since the classification of body shapes should be sensitive to the overall morphological features of the target population. Sensory data on human body shape perception, provided by design experts have also been integrated into the proposed classification method.

\section{EXPERIMENTAL WORK}

In garment design, relative values between body measurements, i.e. differences and ratios, are generally more significant than direct measurements for classifying body shapes. Therefore, it is necessary to identify characteristic indices of body shapes according to the differences and ratios between key dimensions.

\section{Identification to key dimensions of lower body}

As we know, there are thousands of data points related to the lower body in 3D anthropometric data. Only some key dimensions which are significant related to a specific population and a special garment can be selected. The measurements related to the lower body include the vertical dimensions, such as Stature $(S)$, Waist Height $(W H)$, Crotch Height $(\mathrm{CH})$, Knee Height $(K H)$, Thigh Length $(T L)$, and the horizontal dimensions, such as Waist Girth $(W)$, Hip Girth $(H)$, Abdomen Girth $(A)$, Thigh Girth $(T)$, Calf Girth $(C)$, Knee Girth $(K)$ [15].

As known by designers, Knee Height $(K H)$, Thigh Length $(T L)$ and Knee Girth $(K)$ are more relevant to garment pattern construction and less concerned by garment design and body shape[16]. In this context, we only consider eight measurements as key dimensions including Stature, Waist Height, Crotch Height, Waist Girth, Hip Girth, Abdomen Girth, Thigh Girth and Calf Girth, which constitute a measuring vector for a specific human body in this study, for the subject of pants design, which can be defined as: MEASURE $=(S, W H, C H, W, H, A, T, C)$.

\section{The characteristic indices of the lower body shape}

The lower body shapes, generally described by fashion designers using waist shape (WS), hip shape $(H S)$, abdomen shape $(A S)$, leg length $(L L)$, thigh shape (TS) and calf shape (CS). As we only focus on the large and small of various body positions in our research, 15 frequently-used body shape indices are regarded as the characteristic indices of the relevant body shapes as follows.

(1) An waist shape index: $\boldsymbol{W S}=W / S$

Three hip shape indices: $H S_{1}=H-W, H S_{2}=H / W$, $H S_{3}=H / S$

(2) They can constitute an index vector on hip shape: $\boldsymbol{H S}=\left(H S_{1}, H S_{2}, H S_{3}\right)$

(3) Three abdomen shape indices: $A S_{1}=A-W$, $A S_{2}=A / W, A S_{3}=A / S$

They can constitute an index vector on abdomen shape: $\boldsymbol{A S}=\left(A S_{1}, A S_{2}, A S_{3}\right)$

(4) Two leg length indices: $L L_{1}=C H / S, L L_{2}=W H / S$ They can constitute an index vector on leg length: $L L=\left(L L_{1}, L L_{2}\right)$

(5) Three thigh shape indices: $T S_{1}=T / W, T S_{2}=T / H$, $T S_{3}=T / S$

They can constitute an index vector on thigh shape: $\boldsymbol{T S}=\left(T S_{1}, T S_{2}, T S_{3}\right)$

(6) Three calf shape indices: $C S_{1}=C / W, C S_{2}=C / H$, $\mathrm{CS}_{3}=\mathrm{C} / \mathrm{S}$

They can constitute an index vector on calf shape: $C \boldsymbol{S}=\left(C S_{1}, C S_{2}, C S_{3}\right)$

The increase of each index from small to large can describe the change of the shape of the relevant body position from small to large. These characteristic indices directly derived from the corresponding body measurements, can effectively describe the human body shape and permit to perform further studies such as body shape classification.

\section{Sensory evaluation of body shapes}

The concept of sensory evaluation was firstly presented by Amerine in food industry, which is applied to obtain the consumers' subjective experience on food products [17]. Nowadays, it has been expanded asa general scientific discipline that uses human senses to evaluate a specific object [18].

In this study, according to the visual perception of designers on body shapes, each body position can be divided into five sensory classes: "Very Small (VS)", "Small (S)", "Middle (M)", "Large $(L)$ ", "Very 
Large (VL)". Therefore, the evaluation scores can be defined using a linguistic level of $\{V S, S, M, L, V L\}$.

\section{Fuzzy classification model to various lower body positions}

Since there is only one index on waist shape, the characteristic index of the waist shape is just the classification index. However, to each other body position, not all indices can express its shape well. Therefore, we need to identify the most suitable classification index in order to model the classification of body shapes.

The importance degree proposed by rough set theory is a suitable parameter to identify classification index since it only depends on a data-based decision table without prior knowledge. In a decision table, the importance degree of a condition attribute $\{a\}$ related to the decision $D$ is defined by formula (1) [19].

$$
\sigma(a)=\frac{\left|\operatorname{pos}_{C}(D)\right|-\left|\operatorname{pos}_{C-\{a\}}(D)\right|}{U}
$$

where $U$ is a set of body shapes, $C-$ a set of condition attributes, $D=\{d\}$ expresses the decision attribute, $\operatorname{pos}_{C}(D)$ - the $C$ positive domain of $D$, $|\cdot|$ expresses the cardinality of a set.

First, we need to set up a discrete decision table for each lower body position by taking the related characteristic indices as condition attributes and the sensory data as decision attribute. Since the body shapes described by linguistic terms are more significant in garment design, which can be fully expressed by fuzzy set, all the characteristic index values should be fuzzified by proper fuzzy sets.

(1) Fuzzification of characteristic indices

Let $b=\left\{b_{1}, b_{2}, \ldots, b_{n}\right\}$ be the set of human bodies and the $j$-th characteristic index value of $b_{i}$ be $x_{i j}(i=1, \ldots, n$; $j=1, \ldots, q)$. All data should be normalized to interval $[0,1]$ for avoiding the effect of units. Here we normalize $x_{i j}$ to $\bar{x}_{i j}$ by using max-min method [20] as follows.

$$
\bar{x}_{i j}=\frac{x_{i j}-\min }{\max -\min }(i=1, \ldots, n ; j=1, \ldots, q)
$$

Each normalized index value $\bar{x}_{i j}(i=1, \ldots, n ; j=1, \ldots, q)$ can be transformed as five fuzzy sets expressed by five evaluation levels (scores) $\{V S, S, M, L, V L\}$. For this purpose, we denote the following five numerical values.

$$
\begin{aligned}
& X_{j 1}=\min _{1 \leq i \leq n}\left\{\bar{x}_{i j}\right\}, X_{j 3}=\operatorname{median}_{1 \leq i \leq n}\left\{\bar{x}_{i j}\right\}, X_{j 5}=\max _{1 \leq i \leq n}\left\{\bar{x}_{i j}\right\}, \\
& X_{j 2}=\frac{X_{j 1}+X_{j 3}}{2}, X_{j 4}=\frac{X_{j 3}+X_{j 5}}{2}
\end{aligned}
$$

Using these five values, the five fuzzy sets can be expressed respectively by $\tilde{C}_{1}, \tilde{C}_{2}, \tilde{C}_{3}, \tilde{C}_{4}, \tilde{C}_{5}$, each having a triangle or trapezoidal membership function as figure1.

Denote $\mu_{i j}^{(k)}$ as the membership function of the index value $\bar{x}_{i j}(i=1, \ldots, n ; j=1, \ldots, q)$ to the fuzzy set $\widetilde{C}_{k}$ $(k=1,2, \ldots, 5) \cdot \bar{x}_{i j}$ is fuzzified to $\widetilde{C}_{k^{*}}$ if $\mu_{i j}^{\left(k^{*}\right)}=\max _{1 \leq k \leq 5}\left\{\mu_{i j}^{(k)}\right\}$.

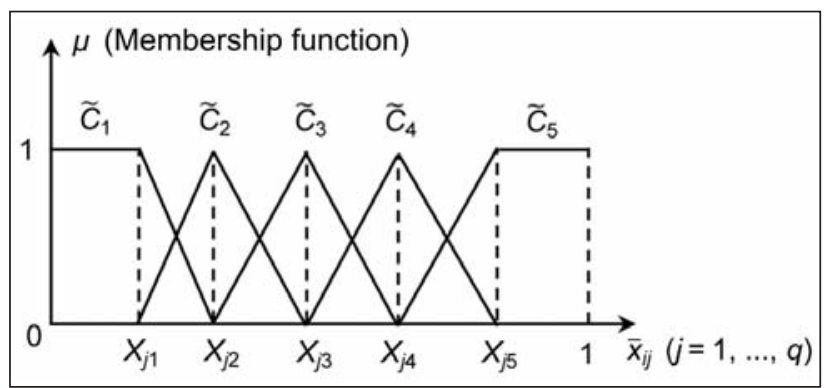

Fig. 1. Fuzzy membership functions of body shape indices

Thus, each index value are expressed by a fuzzy set $\widetilde{C}_{k}(k=1,2, \ldots, 5)$.

(2) Classification algorithm

(a) If all index levels of a body position are consistent, any index can be taken as the classification index.

(b) If the index levels of a body position are inconsistent, the classification index is determined according to the importance degree or similarity degree. (b1) If the importance degrees of various indices are different and their differences are greater than a threshold th, the index with highest importance degree is taken as the classification index.

(b2) If there are at least two indices with the highest importance degree or the differences of the first two importance degrees are less than th, we consider the similarity degrees between a specific body shape and the centers (mean of data) of the various index levels of each body position.

Let $I=\left(x_{1}, x_{2}, \ldots, x_{t}\right)$ be an index vector of a specific body position $b . b$ can expresses hip shape, abdomen shape, leg length, thigh shape or calf shape.

Let $\bar{l}^{(j)}=\left(x_{1}^{(j)}, x_{2}^{(j)}, \ldots, x_{t}^{(j)}\right)$ be a mean vector of the $j$-th index level, where $\bar{x}_{i}^{(j)}$ is the mean of all samples data on the $j$-th index level of the $i$-th index, with $i=1,2, \ldots, t$; $j=1,2, \ldots, 5$.

The similarity degree of $I$ to $\bar{I}^{(j)}$ is defined by

$$
\operatorname{Sim}\left(I, \bar{I}^{(j)}\right)=\exp \left(-\left\|I-\bar{I}^{(j)}\right\|\right)
$$

where "I||l" expresses the Euclidean distance of two vectors.

If all the similarity degrees of $I$ to various levels are different, the shape of body position will be classified to the class with the maximum similarity degree. But if the similarity degrees of /to at least two levels are highest, we need to invite experts to make a judgment.

On this basis, we get the decision rules using logic expression as follows.

Assume $\left(y_{1}, y_{2}, \ldots, y_{t}\right)$ be a group of characteristic indices of $b$, and the index level of $y_{i}$ is denoted as level $\left(y_{j}\right)$ with $i=1,2, \ldots, t$. Let $k, j^{*}$ express the fuzzified value of body shape, with $k, j^{*}=1,2, \ldots, 5$.

(r1) $\forall i$, level $\left(y_{i}\right)=k \rightarrow b$ is " $k$ ".

(r2) $i \neq j \wedge$ level $\left(y_{i}\right) \neq$ level $\left(y_{i}\right) \wedge \sigma\left(y_{i}\right)=$ $=\max _{1 \leq i \leq t}\left\{\sigma\left(y_{i}\right)\right\} \rightarrow b$ is "level $\left(y_{i}\right)$ ". 


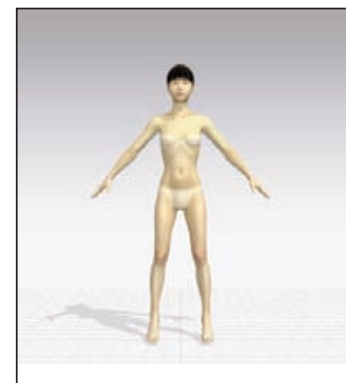

a

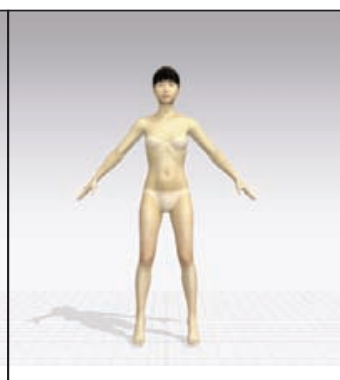

b

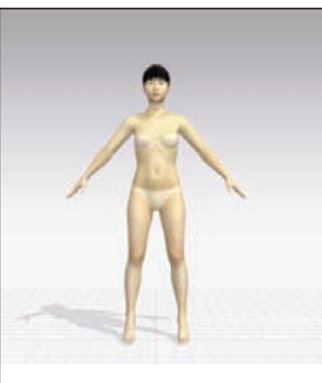

c

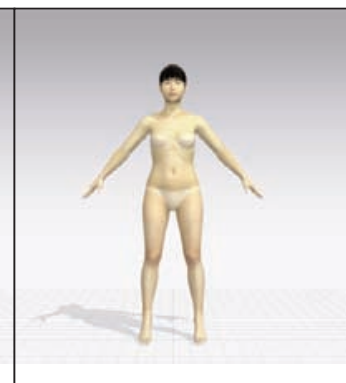

d

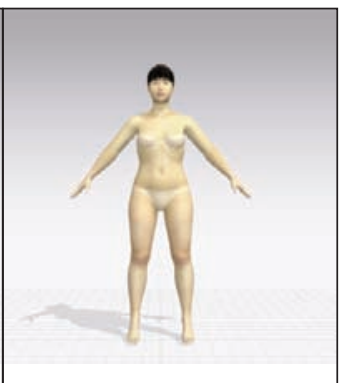

e

Fig. 2. The five virtual human bodies whose hip shapes from "very small" to "very large": $a-V S(69.9 \mathrm{~cm}) ; b-S(75.1 \mathrm{~cm}) ; c-M(84.0 \mathrm{~cm}) ; d-L(95.0 \mathrm{~cm}) ; e-V L(99.0 \mathrm{~cm})$

(r3) $i \neq j \wedge$ level $\left(y_{i}\right) \neq \operatorname{level}\left(y_{i}\right) \wedge \sigma\left(y_{j}\right)=$

$=\sigma\left(y_{i}\right) \wedge \operatorname{Sim}\left(I, \bar{T}^{(j)}\right)=\max \left\{\operatorname{Sim}\left(I, \bar{I}^{(j)}\right)\right\} \rightarrow b$ is " $j "$.

According to our algorithm, any lower body shape can be expressed by a 6-dimension body shape vector (WS, HS, AS, LL, TS, CS) and there are $5^{6}$ kinds of potential body shapes. In practice, body shapes of a specific population are only a fraction of them by analyzing the features of human bodies.

\section{Classification of target population}

We randomly select 125 young women of Central China from 18-25 as samples to set up our model. Two experiments are carried out including 3D body scanning and the sensory evaluation on body shapes. Each experimental result is discretized as a fuzzy set $\tilde{C}_{k}(k=1,2, \ldots, 5)$ by previous proposed method.

According to the previous discussion, we first set up five decision tables on other five body positions except waist shape and then compute the importance degrees of various indices as table 1 .

According to the proposed classification algorithm, we get the following conclusions (here th $=0.01$ )

(1) $\sigma\left(H S_{3}\right)>\sigma\left(H S_{2}\right)>\sigma\left(H S_{1}\right)$ and $\left|\sigma\left(H S_{3}\right)-\sigma\left(H S_{2}\right)\right|>$ $>0.01$, so the classification index of hip shape is $\mathrm{HS}_{3}$.

(2) $\sigma\left(A S_{2}\right)>\sigma\left(A S_{3}\right)>\sigma\left(A S_{1}\right)$ and $\left|\sigma\left(A S_{3}\right)-\sigma\left(A S_{2}\right)\right|>$ $>0.01$, so the classification index of abdomen shape is $A_{2}$.

(3) As $\sigma\left(L L_{1}\right)>\sigma\left(L L_{2}\right)$ and $\left|\sigma\left(L L_{1}\right)-\sigma\left(L L_{2}\right)\right|>0.01$, the classification index of leg length is $L L_{1}$.

(4) $\sigma\left(T S_{2}\right)>\sigma\left(T S_{1}\right)>\sigma\left(T S_{3}\right)$ but $\left|\sigma\left(T S_{2}\right)-\sigma\left(T S_{1}\right)\right|<$ $<0.01$, so the classification index of thigh shape needs to be determined by similarity degree according to the index value vector of thigh shape of each specific human body (It will be discussed in the following example).

(5) $\sigma\left(C S_{2}\right)>\sigma\left(C S_{1}\right)>\sigma\left(C S_{3}\right)$ and $\left|\sigma\left(C S_{3}\right)-\sigma\left(C S_{2}\right)\right|>$ $>0.01$, so the classification index of calf shape is $\mathrm{CS}_{2}$.

Based on above conclusions, we can classify all body shapes in samples and ultimately these samples are divided into 103 classes according to the shapes of 6 lower body positions. It can be seen that there are not too much same body shapes in the samples. Taking the hip shapes classification of the women

\begin{tabular}{|c|c|c|c|}
\hline \multicolumn{4}{|c|}{ Table 1} \\
\hline IMPORTANCE DEGREE OF BODY SHAPE INDICES \\
\hline Index & $\begin{array}{c}\text { Importance } \\
\text { degree }\end{array}$ & Index & $\begin{array}{c}\text { Importance } \\
\text { degree }\end{array}$ \\
\hline$H S_{1}$ & 0.0847 & $L L_{2}$ & 0.8729 \\
\hline$H S_{2}$ & 0.2288 & $T S_{1}$ & 0.5593 \\
\hline$H S_{3}$ & 0.6017 & $T S_{2}$ & 0.5678 \\
\hline$A S_{1}$ & 0.1864 & $T S_{3}$ & 0.3305 \\
\hline$A S_{2}$ & 0.4153 & $C S_{1}$ & 0.4661 \\
\hline$A S_{3}$ & 0.3390 & $C S_{2}$ & 0.8390 \\
\hline$L L_{1}$ & 0.9746 & $C S_{3}$ & 0.1695 \\
\hline
\end{tabular}

with $160 \mathrm{~cm}$ stature as an example, the human body and the Hip Girths corresponding to the center (the mean of the classification index) of each class can be displayed virtually as figure 2 .

\section{RESULTS AND DISCUSSION}

\section{Validation of model}

In our research, since the classification results of body shapes will be used in garment design, they have to fit the perception criteria of designers. Therefore, validity of the model is determined by whether the model output and the perception criteria of designers are consistent or compatible.

The distribution graphs of the model output and perception criterion on the shapes of various body parts are shown in figure 3.

From these distribution graphs, it seems that two distributions are rather close. However, the intuitional analysis is imprecise, which requires further validated by quantized method.

Relative Entropy (Cross Entropy) is introduced to this study, which is often used to measure the degree of approximation between two probability distributions. Suppose that two probability distribution functions are $p(x)$ and $q(x)$ respectively, Relative Entropy (Cross Entropy) [21] of $p(x)$ and $q(x)$ is defined by

$$
D(p, q)=E_{p}\left[\log \frac{p(x)}{q(x)}\right]=\sum_{x \in \chi} p(x) \log \frac{p(x)}{q(x)}
$$

Generally, $D(p, q) \neq D(q, p)$. Therefore, we propose an Improved Cross Entropy by the mean of $D(p, q)$ and $D(q, p)$ as follows. 


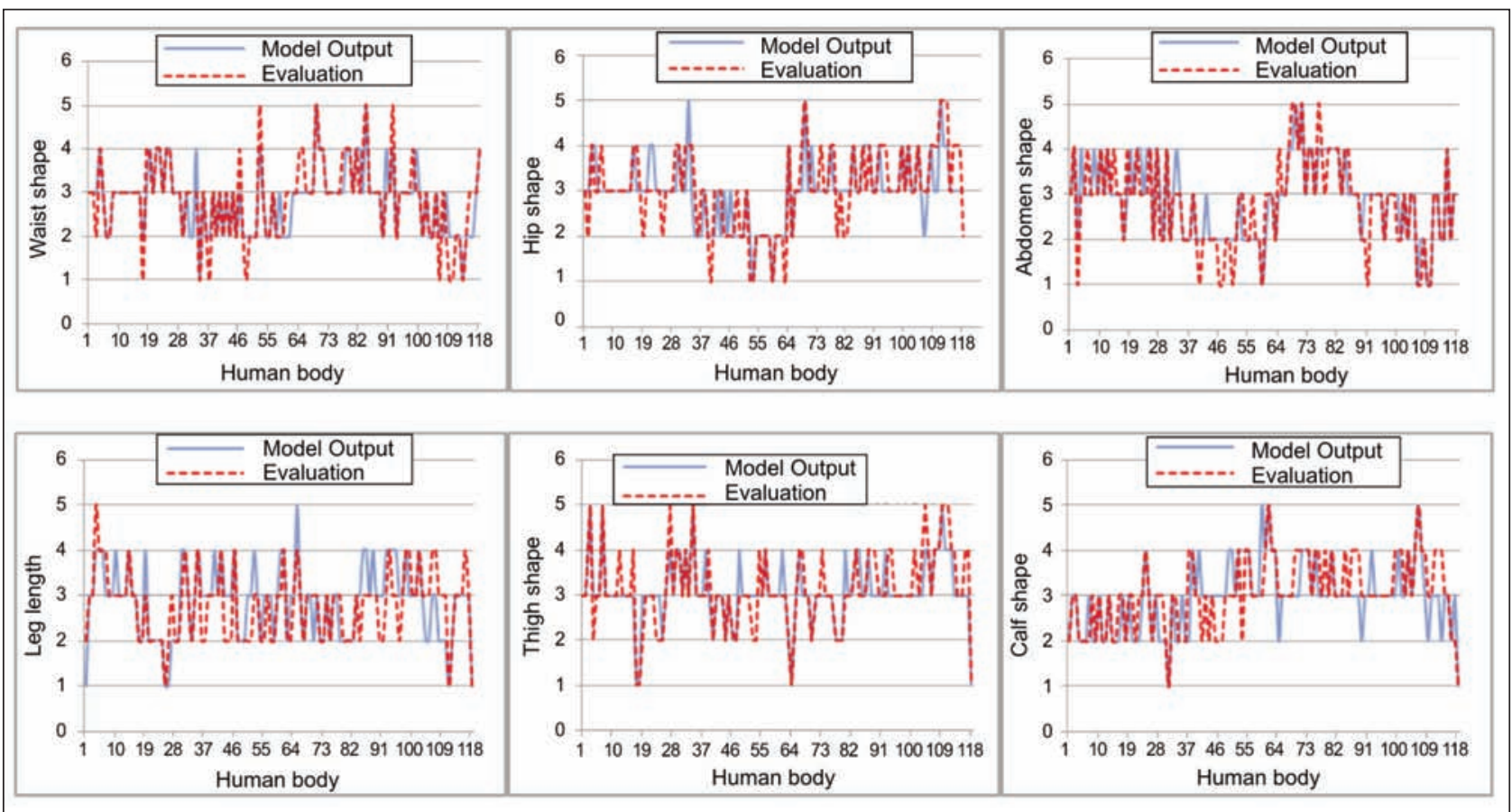

Fig. 3. Comparison between predict results of model and perception criterion on body shapes classification. $1,2,3,4$ and 5 expresses respectively $V S, S, M, L$ and $V L$

$$
\begin{aligned}
I D(p, q) & =\frac{1}{2}[D(p, q)+D(q, p)]= \\
& =\frac{1}{2}\left[\sum_{x \in \chi} p(x) \log \frac{p(x)}{q(x)}+\sum_{x \in \chi} q(x) \log \frac{q(x)}{p(x)}\right]
\end{aligned}
$$

The smaller cross entropy is, the closer $p(x)$ and $q(x)$ is.

In our research, $\chi=\{V S, S, M, L, V L\}, p(x)$ is the frequency distribution function of model output and $q(x)$ - the frequency distribution function of perception criteria of experts. The cross entropies related to the shape of each body position is listed in table 2 .

Table 2

\begin{tabular}{|c|c|c|c|c|c|}
\hline \multicolumn{7}{|c|}{ IMPROVED CROSS ENTROPYOF EACH BODY } \\
POSITION \\
\hline $\begin{array}{c}\text { Body } \\
\text { part }\end{array}$ & $\begin{array}{c}\text { Cross } \\
\text { entropy }\end{array}$ & $\begin{array}{c}\text { Body } \\
\text { part }\end{array}$ & $\begin{array}{c}\text { Cross } \\
\text { entropy }\end{array}$ & $\begin{array}{c}\text { Body } \\
\text { part }\end{array}$ & $\begin{array}{c}\text { Cross } \\
\text { entropy }\end{array}$ \\
\hline Waist & 0.0548 & Abdomen & 0.0417 & Thigh & 0.0563 \\
\hline Hip & 0.0435 & Leg & 0.0220 & Calf & 0.0258 \\
\hline
\end{tabular}

It is clear that all of these results are less than 0.1 , which shows that the output of this model is rather close to the perception criterion. According to the above discussions, we can believe that the proposed model has a good classification capability on body shapes.

\section{An illustrate example}

We give an example for classifying a real human body by using the proposed model. We randomly select a human body from the target population, whose 3D body scanning result is presented in figure 4 . Themeasuring vector by $3 \mathrm{D}$ body scanning is as follows.
The measuring vector is measure $=(166.5,105$, 76.3, 66, 91.6, 77.6, 55, 32.7) and all units are "cm". Thus, $\boldsymbol{W S}=0.3962$ and the related index vectors are computed as follows.

$\boldsymbol{H S}=(25.6,1.3879,0.5498), \boldsymbol{A S}=(11.6,1.1758,0.4658)$,

$\boldsymbol{L} L=(0.4580,0.6303), \boldsymbol{T S}=(0.8333,0.6004,0.3301)$,

CS $=(0.4955,0.3570,0.1963)$.

They can be normalized as follows

normal $(\boldsymbol{W S})=0.4759$, normal $(\boldsymbol{H S})=(0.5972,0.5270$, 0.5038), normal $(\boldsymbol{A S})=(0.6360,0.5190,0.4950)$, normal $(\boldsymbol{L} L)=(0.4907,0.5183)$, normal $(T S)=(0.5603$, $0.5332,0.5373)$, normal $(\boldsymbol{C S})=(0.5008,0.4731,0.4776)$. After fuzzy operation, we obtain the discretized index vectors as:

fuzzified $(\boldsymbol{W S})=\tilde{C}_{2}$, fuzzified $(\boldsymbol{H S})=\left(\tilde{C}_{4}, \tilde{C}_{4}, \tilde{C}_{3}\right)$, fuzzified $(A S)=\left(\tilde{C}_{4}, \widetilde{C}_{4}, \tilde{C}_{3}\right)$, fuzzified $(L L)=\left(\tilde{C}_{3}, \widetilde{C}_{4}\right)$, fuzzified $(T S)=\left(\tilde{C}_{5}, \widetilde{C}_{4}, \tilde{C}_{4}\right)$, fuzzified $(C S)=\left(\tilde{C}_{3}, \tilde{C}_{2}, \tilde{C}_{2}\right)$. According to the proposed classification principle, we can learn the shapes of various body positions of the woman as follows: the waist shape is " $\tilde{C}_{2}$ ", the Hip shape is " $\tilde{C}_{3}$ ", the abdomen shape is " $\tilde{C}_{4}$ ", the leg length is " $\tilde{C}_{3}$ ", and the calf shape is " $\widetilde{C}_{2}$ ".

The thigh shape needs to be identified by using similarity degree. We only need to consider two indices $T S_{1}$ and $T S_{2}$, on which the mean vectors of various index levels is as follows

$$
\begin{aligned}
& \bar{l}^{(1)}=(0.4078,0.4480), \quad \bar{l}^{(2)}=(0.4664,0.4822), \\
& \bar{l}^{(3)}=(0.5026,0.5049), \bar{l}^{(4)}=(0.5426,0.5139), \\
& \bar{l}^{(5)}=(0.5476,0.5490) .
\end{aligned}
$$

And the index vector of thigh shape and $I=(0.5603$, 0.5332). Thus,

$\operatorname{Sim}\left(I, \bar{I}^{(1)}\right)=0.8397, \operatorname{Sim}\left(I, \bar{I}^{(2)}\right)=0.8986, \operatorname{Sim}\left(I, \bar{I}^{(3)}\right)=$ $=0.9377, \operatorname{Sim}\left(I, I^{(4)}\right)=09742, \operatorname{Sim}\left(I, I^{(5)}\right)=0.9799$. 


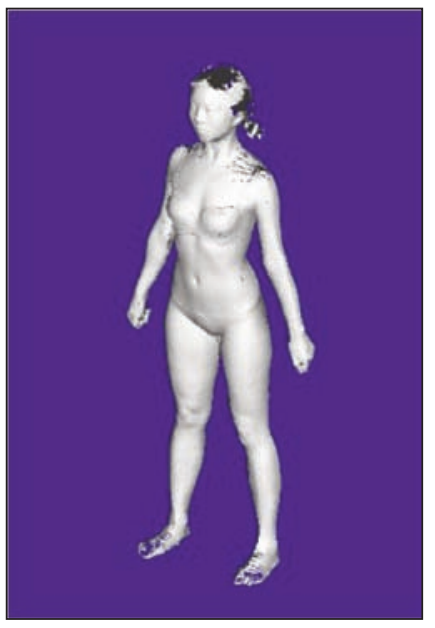

Fig. 4. The 3D body scanning image of the human body to be analyzed

As a result, $\operatorname{Sim}\left(I, \bar{I}^{(5)}\right)=\max _{j}\left\{\operatorname{Sim}\left(I, \bar{I}^{(j)}\right)\right\}$. Therefore, the thigh shape of this woman is " $\widetilde{C}_{5}$ ". Thus, the lower body shape of this woman is (WS(S), $\mathrm{HS}(M), \mathrm{AS}(L), \mathrm{LL}(M), \mathrm{TS}(V L), \mathrm{CS}(S))$.

\section{CONCLUSIONS}

Body shape classification permits to divide the whole human bodies into different clusters, which has similar body dimensions. It is significant for garment size identification and customized garment design, and strongly related to the distribution of body shapes in a target population. This paper proposes a classification algorithm for classifying the lower body shapes of the target population into different classes. By following the principle of garment design process, the proposed algorithm utilizes the exploitation of designer's perception on body shapes instead of specific numerical data on body measurements. In this context, fuzzy techniques seem to be relevant tools for modeling and processing uncertain linguistic evaluation data describing body shapes. In the proposed algorithm, the key index data related to the linguistic descriptors, provided by designers, are first fuzzified. Based on these fuzzy data and sensory data, we set up a decision table for the lower body shape classification. In this decision table, all the key indices constitute the condition attribute sets while the sensory data is regarded as decision attribute. Next, we gather all similar body shapes into one cluster using equivalence relations established by rough sets. In fact, rough sets theory has shown in various applications with its exceptional abilities for classification of decision tables. For solving conflicts between index values, we compute the importance degrees of attributes and select the index with the biggest importance degree as the classification index if their importance degrees are different. The similarity degree of a body shape to the center of each class of body shapes will be considered if the importance degrees of the indices are equal and the index with maximum similarity degree will be regarded as the classification index. Ultimately, the shape of every body position of a female's lower body is divided into five classes by using rough set method: very small (VS), small $(S)$, medium $(M)$, large $(L)$, very large $(V L)$, which are fit for human's perceptional recognition to body shapes. According to the validation of the model and an illustrative example, we believe the proposed algorithm is effective.

In practice, the proposed classification idea can be also applied to the classification of upper body shapes and other populations such as south-Africa people.

\section{ACKNOWLEDGEMENTS}

The authors would like to express their appreciation for the supports of Hubei Province Education Department Project (No. Q20141603) in China, Science \& Technology Guidance Project (No. 2015081) of China National Textile and Apparel Council and the 2015 produce-learn-research fund Project (No. 22) of Wuhan Textile University in China.

\section{BIBLIOGRAPHY}

[1] Zakaria, N. Body shape analysis and identification of key dimensions for apparel sizing systems, In: Anthropometry Apparel Sizing \& Design, 2014, pp. 95-119.

[2] Otieno, R.B. and Fairhurst, C. The development of new clothing size charts for female kenyan children, Part I: Using anthropometric data to create size charts, In: Journal of the Textile Institute, 2000, vol. 2, issue 91, pp. 143-152.

[3] Hsu, C. Applying a bust-to-waist girth ratio approach to develop body measurement charts for improving female clothing manufacture, In: Journal of the Chinese Institute of Industrial Engineers. 2008, vol. 3, issue 25, pp. 215-222.

[4] Tsunawake, N., et al. Classification of body shape of male athletes by factor analysis, In: US National Library of Medicine National Institutes of Health, 1994, vol. 6, issue 13, pp. 383-392.

[5] Takabu, H. Analysis and classification of human body shape aimed applying to clothing design, In: Journal of Home Economics of Japan, 2008, vol. 1, issue 59, pp. 687-6977.

[6] Hasler, N., et al. A Statistical model of human pose and body shape, In: Computer Graphics Forum, 2009, vol. 2, issue 28 , pp. 337-346.

[7] Choi, Y.L. and Yun, J.N. Classification of upper lateral body shapes for the apparel industry, In: Human Factors \& Ergonomics in Manufacturing, 2010. vol. 5, issue 20, pp. 378-390. 
[8] Huang, C.Y. Study on classification of body shape and size grading on young women of Quanzhou District, In: Advanced Materials Research. 2014, vol. 1, issue 989-994, pp. 5319-5322.

[9] Olaru, S., Filipescu, E. and Niculescu, C. Morphological indicators for characterization of women thorax and basin shape, for garment design in customised system, In: Industria Textila, 2011. 62, 6, pp. 289-295.

[10] Zadeh, L.A. Fuzzy sets, In: Information \& Control, 1965, vol. 3, issue 8, pp. 338-353.

[11] Chen, Y. From body measurements to human perception of body shapes: Modeling using intelligent techniques, In: Computational Intelligence, 2010, vol. 4, issue 1, pp. 1084-1089.

[12] Wang, L.C., et al. Intelligent fashion recommender system: Fuzzy logic in personalized garment design, In: HumanMachine Systems (IEEE Transactions), 2015, vol. 1, issue 45, pp. 95-109.

[13] Dong, M., Zeng, X, and Koehl, L. Dynamic fuzzy clustering of lower body shapes for developing personalized pants design, In: Conference on Uncertainty Modelling in Knowledge Engineering and Decision Making, 2016, vol. 10, issue 1, pp. 898-904.

[14] Pawlak, Z. Rough Sets: Theoretical aspects of reasoning about data, Kluwer Academic Publishers, 2010.

[15] Ben Azouz, Z., et al. Characterizing human shape variation using $3 D$ anthropometric data, In: The Visual Computer, 2006, vol. 5, issue 22, pp. 302-314.

[16] Olaru, S., et al. Morphological assessment of human body for clothing patterns design, In: Industria Textila, 2013. vol. 5, issue 64, pp. 254-259.

[17] Amerine, M.A., Pangborn, R.M., and Roessler, E.B. Principles of sensory evaluation of food, In: Principles of Sensory Evaluation of Food, 1965, vol. 1, issue 1, pp. 159-176.

[18] Wikipedia contributors, Sensory analysis. In: Wikipedia, 2016.

[19] Pawlak, Z. Rough set theory and its applications to data analysis. In: Cybernetics \& Systems, 1998, vol. 29, issue 29, pp. 661-688.

[20] Uragun, B. and Rajan, R. Developing an appropriate data normalization method, In: IEEE/ACM Transactions on Computational Biology \& Bioinformatics, 2011, vol. 2, issue 2, pp. 195-199.

[21] Zhang, M. Information theory and statistics, In: Wiley, 1959, vol. 288, issue 54, pp. 301.

Authors:

\section{MIN DONG ${ }^{1}$ \\ YAN HONG ${ }^{2,3}$ \\ JUNJIE ZHANG ${ }^{1}$ \\ KAIXUAN LIU 4 \\ MELISSA WAGNER ${ }^{3}$ \\ HUIYU JIANG ${ }^{1}$}

${ }^{1}$ Wuhan Textile University, Wuhan 430020, China

${ }^{2}$ College of Textile and Clothing Engineering, Soochow University, Suzhou 215021, China

${ }^{3}$ Technical University of lasi, DimitrieMangeron Bd., 53, lasi - 700050, Romania

${ }^{4}$ Clothing and art college, Donghua University, Shanghai 200051, China

\section{Corresponding author:}

HUIYU JIANG

e-mail: min.dong@ensait.fr 